\title{
Application of assimilation and filtration methods for satellite water sensing data for plankton population evolution processes predictive modeling *
}

\author{
A. L. Leontyev ${ }^{1,2,3}$, A. V. Nikitina ${ }^{1,2,3}$, M. I. Chumak ${ }^{3,4 * *}$ \\ ${ }^{1}$ Southern Federal University, Taganrog, Russian Federation \\ ${ }^{2}$ Supercomputers and Neurocomputers Research Center, Taganrog, Russian Federation \\ ${ }^{3}$ Scientific and Technological University «Sirius», Sochi, Russian Federation \\ ${ }^{4}$ Don State Technical University, Rostov-on-Don, Russian Federation
}

The article is devoted to the analysis and implementation of satellite observations data assimilation and filtration highly technological methods used in the hydrodynamics and biological kinetics of shallow reservoirs mathematical models development and verification. The paper considers the using neural networks possibility and describes various methods for filtering images obtained from satellite earth sensing data. The plankton populations evolution mathematical model in the Azov sea is considered. Its calibration and verification is carried out using observations satellite assimilation methods. The purpose of this work is to create a software tool used at the preliminary and final stages of hydrobiological processes in shallow water mathematical modeling.

Keywords: mathematical modeling, phytoplankton evolution, shallow water reservoir, satellite sensing data, neural net-works, filtering methods.

Introduction. Many scientists are engaged in hydrodynamic and biological kinetics processes mathematical modeling. Fundamental works in the field of creating mathematical models, developing methods for diagnosing and predicting changes in aquatic ecosystems include the works of such authors as Lotka A.J. [1], Volterra V. [2], which considered issues of interspecific interaction, Logofet D.O. [3], whose work considered the mechanisms of population change. Hutchinson G. E. studied the flora and fauna of lakes, Monod J. [4] described the influence of bacterial cultures and participated in the discovery of genetic control of the synthesis of enzymes and viruses. Mitscherlich E. A. discovered the law of action of growth factors and presented a new view on the science of plants [5]. Odum H.T. was one of the founders of system ecology and explained ecological structures from energy systems [6]. Gause G.F., being one of the founders of ecology, studied models of interspecies interactions and protozoan organisms [7]. Vinberg G.G. [8] was engaged in research related to the processes of nutrition and growth of aquatic organisms, Abakumov A.I. [9] is actively engaged in the development of methods for optimizing the modeling of aquatic ecosystems. Menshutkin V.V. [10] and Rukhovets L.A. [11] researched the distribution of impurities in reservoirs, Vorovich I.I., and Gorstko A.B. [12] developed schemes for the rational use of water resources. Marchuk G.I. [13] was one of the largest specialists in the field of development of mathematical models of water ecosystems. Jorgensen S.E., Meyer H., Firiis M. [14] studied the issues of Limnology and ecological modeling. Vollenweider R.A. investigated the eutrophication of lakes and the effect of phosphorus on the

\footnotetext{
* The reported study was funded by RFBR, project № 19-31-51017.

**E-mail: Leontyev_Anton@mail.ru, Nikitina.vm@gmail.com, Chumaaak1908@gmail.com.
} 
concentration of chlorophyll «a». Russian and foreign scientists have made a great contribution to the development of principles, mathematical models, and approaches widely used in solving scientific and practical problems of aquatic ecosystems. Phytoplankton is the base of the trophic pyramid of the shallow water reservoir biogeocenosis, the main link in the food chain «phytoplankton-zooplanktonfish». With the flow of rivers into reservoirs come nutrients-compounds of nitrogen, silicon, and phosphorus, causing a surge in the growth of the phytoplankton population, called «blooming». The analytical model of «reservoir blooming» was described in the works of Krestin S.V. and Rosenberg G.S., where a possible explanation of the phenomenon of blue-green algae population outbreaks and the more complex process of «flowering waves» along the reservoir profile is given within the framework of interactions between species competition systems and «predator-prey». On the example of the North Sea plankton dynamics model, J. Steele described models for combining various hypotheses about food behavior, leaving a minimum of attention to the features of the spatial distribution of organisms [15]. In the work [16] J. Dubo studied the causes of the formation of spatial heterogeneity in the North Sea, taking into account two factors: the trophic relationships between phyto- and zooplankton and the speed of water flows during diffusion.

Mathematical models of these authors were developed and tested based on retrospective and expedition data, which did not allow creating short-term forecasts, much fewer forecasts in real-time. With the development of technology, the speed of predictive modeling increases, so in the work of A.I. Sukhinov [17-20], the method of decomposition of the numerical field of a supercomputer is considered, which is necessary to increase the efficiency of calculations. The main goal of both the above-mentioned and most works on the optimization of computational structures used in mathematical modeling of hydrodynamic and biological kinetics processes is to accelerate calculations, and not to ensure the stability of providing forecasts.

Some of the input data required for making forecasts can still be obtained in the course of expedition research in the water area of reservoirs or through observations at coastal hydrometeorological stations, but using retrospective data and regression analysis methods, it is possible to obtain only an approximate value of these parameters with some error.

Besides, input data for mathematical modeling can be obtained using methods of processing data from satellite earth sensing (SES). SES data allows you to track changes in the environmental situation of reservoirs in real time and make operational forecasts of further development of the situation in an accelerated time, which is especially important in the event of emergencies. This type of data is presented as snapshots, which must be filtered out of noise at the first stage. At the second stage, it is necessary to localize the researched area and, if necessary, compare it with the color scale - to implement the process of data assimilation. These two stages may change places, but they cannot be effectively implemented based on analytical methods alone.

In this regard, the purpose of this work is to analyze and implement methods for filtering and assimilation of SES data for predictive modeling of the evolution of phytoplankton populations.

Problem statement. Consider the mathematical model of phytoplankton evolution described in [21]. Figure 1 shows a diagram of a water body in the form of a closed pool, bounded: $\sigma$ by side surface of a water body; $\Sigma_{0}$ by surface of the sea, which we will consider undisturbed; $\Sigma_{H}=\Sigma_{H}(x, y)$ by the bottom surface. $\Sigma=\Sigma_{0} \cup \Sigma_{H} \cup \sigma, \Sigma$ is the domain boundary $G$, which is piecewise smooth for all $t \in\left(0, T_{0}\right]$. 


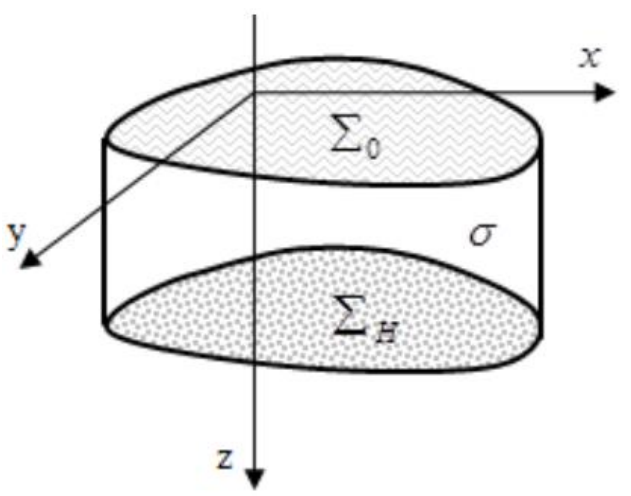

Fig. 1. Water-body scheme

Consider the diatoms dynamics model, which is important in the diet of pelagic fish:

$$
\begin{aligned}
& \frac{\partial q_{i}}{\partial t}+\operatorname{div}\left(\boldsymbol{U} q_{i}\right)=\mu_{i} \Delta q_{i}+\frac{\partial}{\partial z}\left(v_{i} \frac{\partial q_{i}}{\partial z}\right)+\varphi_{i}, i \in\{1,2,3\} \\
& \varphi_{1}=\left(\alpha_{0}+\gamma q_{3}\right) \psi q_{1}-\delta q_{1} \\
& \varphi_{2}=B\left(S_{p}-q_{2}\right)-\left(\alpha_{0}+\gamma q_{3}\right) \psi q_{1}+f ; \\
& \varphi_{3}=k_{3} q_{1}-\varepsilon q_{3},
\end{aligned}
$$

where indexes indicate the type of substance: 1 is the phytoplankton concentration $(X)$ (diatom Sceletonema costatum); 2 is the nutrients $(S)$ (silicon); 3 is the metabolite $(M) ; \boldsymbol{U}=(U, \mathrm{~V}, \mathrm{~W})$ is the components of the water flow velocity vector; $\alpha=\left(\alpha_{0}+\gamma q_{3}\right)$ is the growth rate of phytoplankton; $\alpha_{0}$ is the growth rate of phytoplankton in the absence of a metabolite; $\gamma$ is the impact parameter; $\mu_{i}, v_{i}$ - д are the diffusion coefficients in the horizontal and vertical directions of substances $q_{i}, i \in\{1,2,3\}$ respectively; $\delta$ is the coefficient of phytoplankton loss due to die-off (specific mortality), which takes into account the influence of salinity $(C) ; B$ is the specific rate of pollutant intake; $S_{p}$ is the maximum possible concentration of the contaminant; $f(x, y, z)$ is the function of the pollution source; $k_{3}$ is the coefficient of excretion; $\varepsilon$ is the coefficient of metabolite decomposition; $\Delta$ is the two-dimensional Laplace operator; $\psi(I, T, S, C)$ is the coefficient that takes into account the influence of light $(I)$, temperature $(T)$, nutrient $(S)$ and salinity $(C)$ on the growth of phytoplankton cells $(X)$.

Add the initial conditions to (1):

$q_{i}(x, y, z, 0)=q_{i 0}(x, y, z), i \in\{1,2,3\},(x, y, z) \in \bar{G}, t=0$,

and boundary conditions:

$$
\begin{aligned}
& q_{i}=0 \text { on } \sigma, \text { if } U_{n}<0 ; \frac{\partial q_{i}}{\partial n}=0 \text { on } \sigma, \text { if } U_{n} \geq 0 ; \\
& \frac{\partial q_{i}}{\partial z}=0 \text { on } \Sigma_{0} ; \frac{\partial q_{i}}{\partial z}=-\varepsilon_{i} q_{i} \text { on } \Sigma_{H}, i \in\{1,2,3\} .
\end{aligned}
$$

In (3) $\varepsilon_{1}$ is the coefficient, that takes into account the flooding of algae; $\varepsilon_{2}, \varepsilon_{3}$ are the coefficients that takes into account the absorption of bottom sediments of a nutrient and a metabolite.

In this model problem, it is necessary to take into account a large number of parameters, some of which can be obtained based on the assimilation of SES data. These important parameters include the initial distribution of phytoplankton, water flow rate, water temperature, and so on.

Filtering methods. Let's briefly consider the main algorithms that can be used for filtering images of water bodies obtained during SES. 
Adaptive filtering. The iterative algorithm allows for increasing the speed of image synthesis using the progressive Monte Carlo ray-tracing method [22]. The authors suggest using a filter with an Epanechnikov core, the size of which varies depending on the density of the distribution of Monte Carlo samples according to the empirical law. This algorithm does not take into account the features of the scene, which leads to blurred borders on the image.

Multidimensional filtering is an algorithm used for processing arbitrary signals [23]. The filter allows you to take into account many dimensions that contain information about the image. This filter has proven itself well, although it shows a high speed of operation.

Filtering with a wavelet transform. This method is used for filtering real-time lighting [24]. The advanced bilateral filter with a-Trous wavelet transform is based on additional transformations using an additional weight function used to define borders on the image. The calculations use additional pixel data, such as coordinates in world space and the direction of the normal. The weight function is calculated based on the proximity of pixels in three directions. This filtering allows you to keep the borders clear, but color spots may appear on uniform surfaces. On average, this filter can process up to four frames per second, which allows you to use it in real-time.

Adaptive distribution of Monte Carlo samples. This method is based on the fact that each point is defined by a multidimensional function in the image space, which is anisotropically interpolated [25]. For the following selections, positions are determined closer to abrupt changes in the multidimensional function, which corresponds to areas in the image that need more selections.

Guided filtering. The filter is based on the need to process the image, operating with additional information about each of the pixels [26]. If the information is selected correctly, this filter may show better results than the bilateral filter. Using guided filtering for Monte Carlo ray tracing involves dividing lighting into primary and secondary. The latter is processed by a guided filter, and additional information is the norm and depth maps, as well as the color buffer. This method is characterized by the high quality of the final image and high performance.

Probabilistic filtering. In this type of filtering, for each pixel of the image, all samples are clustered by the depth of the ray, and, according to the Poisson process assumption, the distribution of samples in a cluster of one pixel is compared with the distribution in clusters of neighboring pixels [27]. The filter also uses information about normals and depth to detect boundaries. This algorithm allows you to get an image with a small number of samples per pixel, which is better than crossbilateral filtering.

There are many methods of image filtering in the scientific literature, but some of them have one significant drawback for predictive modeling of hydrodynamic and biological kinetics processes - blurring of borders and contours. Depending on the resolution of the image, blurring the border by a few pixels may correspond to blurring the field of concentration of phytoplankton populations or pollutants for hundreds of meters across the reservoir, and consequently, as a result of erroneous actions on the part of government and environmental agencies.

Here is an example of guided filtering. Fig. 2a shows data on the dynamics of plankton population evolution during the emergency («water blooming» of the sea of Azov, which caused fish oversea phenomena) in July 2013, obtained using the SES. Fig. 2b shows filtered data that can be used in the future to build a forecast of changes in emergencies in advance of time. 


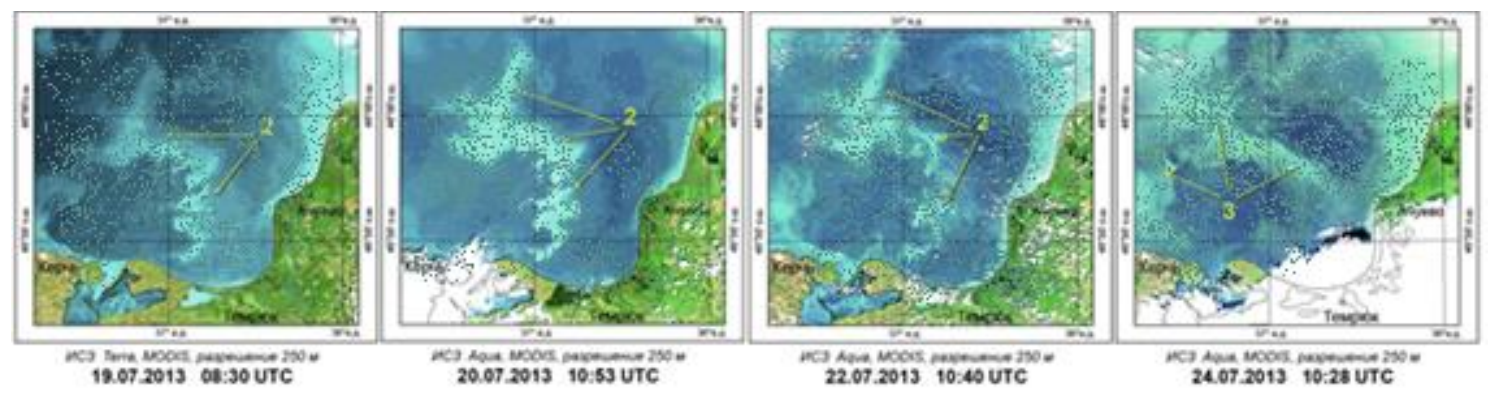

a)

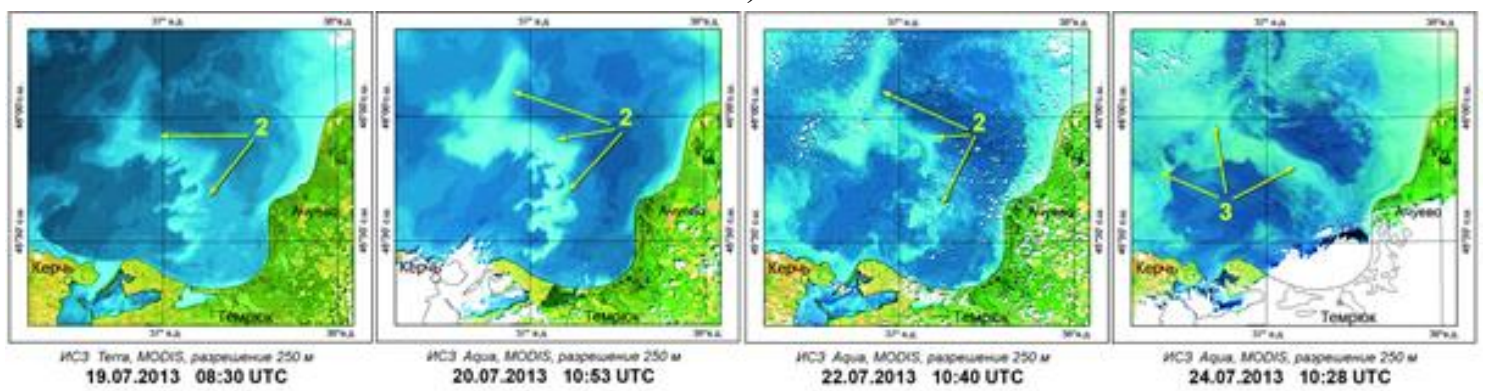

b)

Fig. 2. Changes in phytoplankton concentration in the Azov sea:

a) before filtering; $b$ ) after guided filtering

Fig. 2a shows multiple interference patterns. Different filters can be applied to eliminate them, but since we can get SES data in real-time, we can only consider algorithms focused on filtering images by ray tracing without blurring the boundaries of displayed objects, which justifies the choice of this filter.

After the image filtering process is complete, the task of assimilating the obtained data arises, that is, determining the boundaries of the propagation zone of the process or phenomenon of interest, determining the concentration or correspondence with the color scale, and converting the image data into numerical arrays. One of the technologies that can solve these tasks is the neural network.

Neural network. Neural networks can be used for many tasks, including data analysis, optimization, and compression, approximation, prediction, clustering, decision making, and detection. Each of these directions can be used in solving hydrodynamics and biological kinetics model problems, but mostly neural networks are used for detection - recognition, and classification of images.

In the last decade, special attention has been paid to convolutional neural networks and deep learning. Using these technologies allows you to extract information from hyperspectral data in SES. Additionally, multi-layer networks-auto-encoders allow data compression with the inclusion of spatial and spectral information in images. This, in turn, makes it possible to get a more accurate solution to the problems of recognizing and detecting objects in the image. Together with the theory of deep learning, this method allows analyzing information at several levels of representation and identifying previously unfixed connections between phenomena [28, 29].

Convolutional neural networks are networks that train with a teacher and can be represented as a multi-stage cascade of direct propagation. In the classical topology neural network (Fig. 3), there are 3 main types: convolutional layers, association layers, and direct propagation layers with training. 


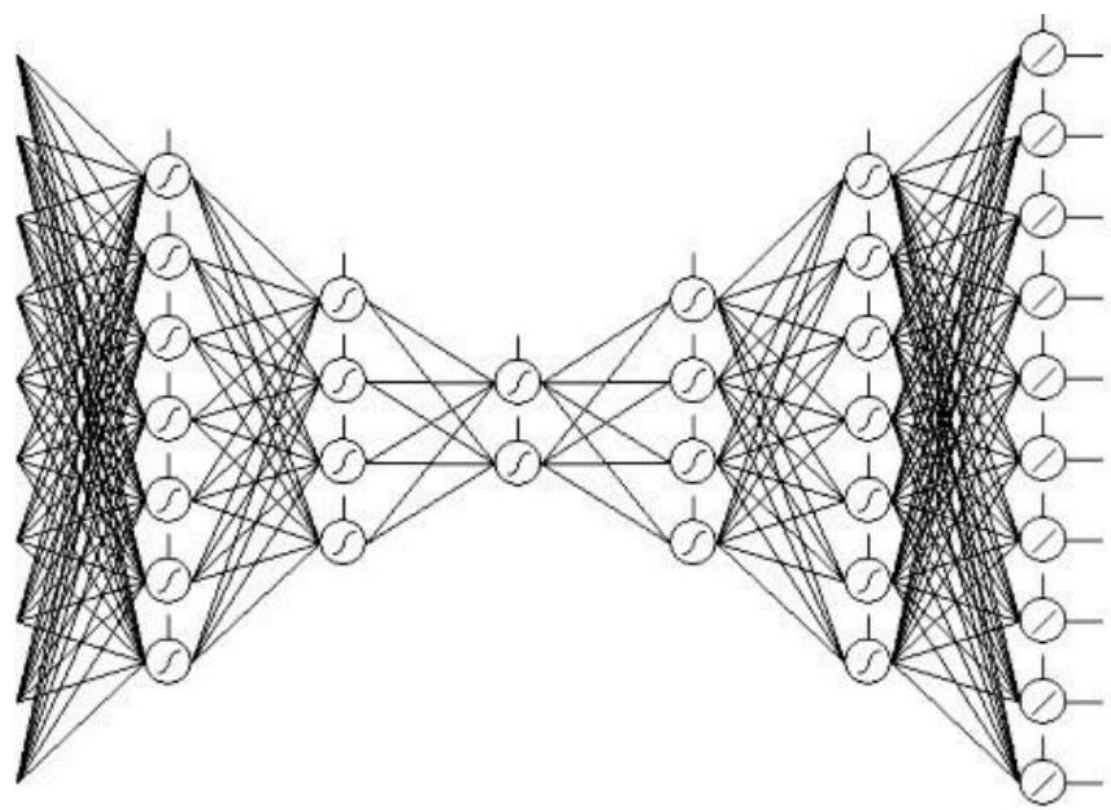

Fig. 3. Classical topology of a convolutional neural network

The output layer of such a network is a feature map in which an element of the output layer is obtained by applying a convolution operation between the input layer and the final subdomain under the influence of a certain filter and the subsequent action of a nonlinear activation function. Pudding layers operate lowering the sampling level for the feature map.

Multistage networks assume the presence of several fully connected layers after a cascade of convolutional layers and pooling layers, which allows you to transform the matrix of pixel values of the input image into a matrix of final features using the direct propagation network method. Parameters of convolutional neural networks are configured using the method of backpropagation of errors, implemented using classical gradient descent.

Convolutional networks with deep learning demonstrate great capabilities in solving large image processing problems of high resolution due to two features:

- $\quad$ they have great learning opportunities;

- $\quad$ allow to use accumulated databases, which allows you to compensate for the lack of data that is previously unknown in the model problem.

Training large convolutional networks with deep learning that contain many parameters is a time-consuming task. Proper training requires large databases. If this condition is met, such networks can be used in computer vision tasks, such as classification of visual scenes, detection of images (image fragments), semantic segmentation of images, image recognition, and image recovery. 


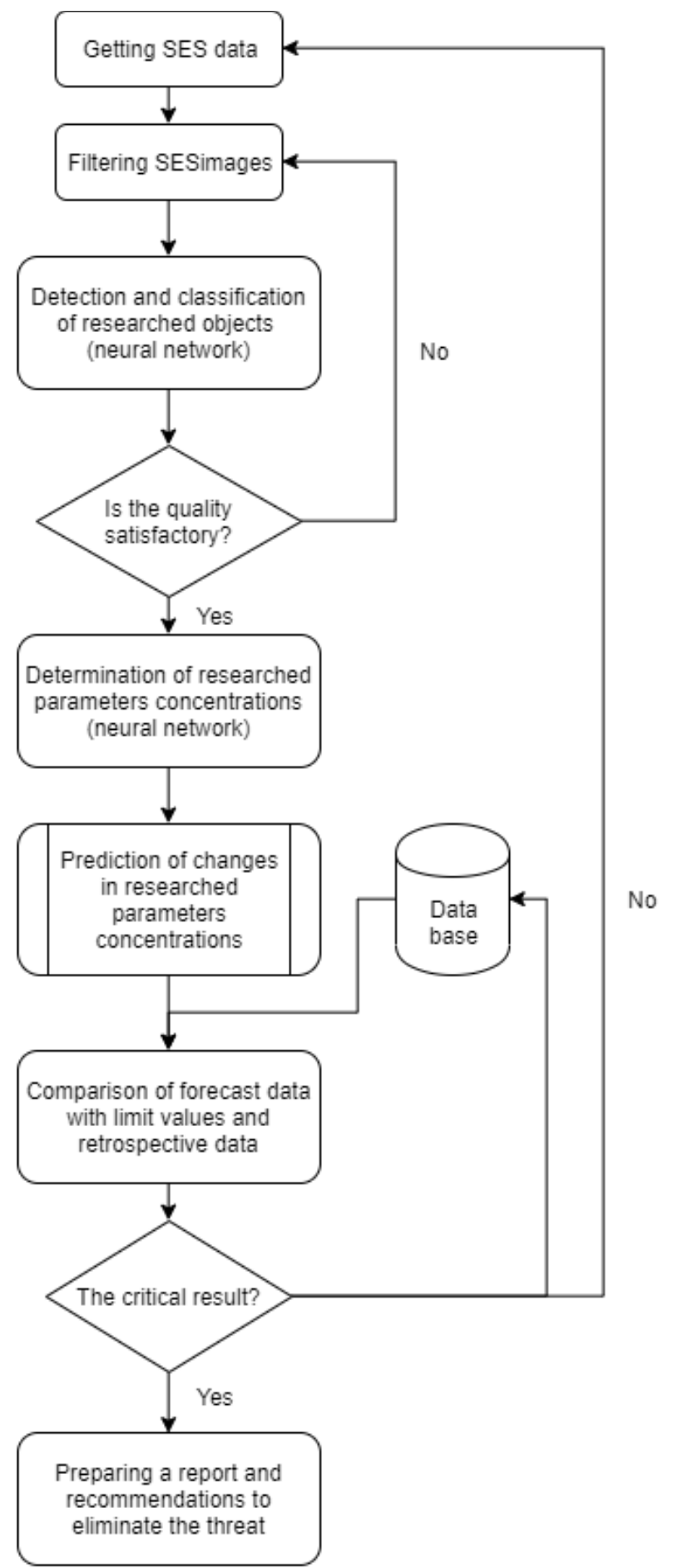

Fig. 4. Scheme of predictive modeling algorithm using filtering and neural net-work approach

The main idea of using these technologies is to improve the accuracy of predictive modeling. The following algorithm was developed for successful implementation of the model problem:

- $\quad$ obtaining SES data that has information value in the conditions of the model problem;

- $\quad$ filter images to improve image quality and accuracy;

- determination and classification of phytoplankton and pollutants distribution fields using a neural network; 
- $\quad$ if necessary: additional filtering of objects defined in the previous step;

- determination of phytoplankton and pollutants concentrations using convolutional neural network and auto-encoders data.

- $\quad$ calculation and prediction of changes in concentrations of selected pollutants and phytoplankton;

- $\quad$ comparison of the data obtained at the previous stage with the maximum permissible concentrations (PC) of the studied components of the model problem and historical data;

- $\quad$ based on the developed and trained neural network, making a decision on the need to prepare a report and recommendations for operational intervention by the relevant authorized authorities of the region.

Fig. 4. shows the flow diagram of the developed algorithm.

Most of the work, namely detection and determination of concentrations of pollutants, and phytoplankton in emergencies, as well as the problem of decision-making, is solved using neural networks and can be implemented on graphics accelerators and programmable logic integrated circuits (FPGAs). Filtration can be performed by various methods, which is why an additional filtration stage is allowed. If the contours on the processed image remain blurred after the first stage of filtering, then the subsequent stages of detection and filtering minimize the negative effect.

The prediction block can be focused on a multi-core processor, as well as specialized graphics accelerators and super-computers.

Discussion and conclusions. The paper shows the relevance of using high-tech methods of filtering and assimilation of SES data. The image filtering modern methods applied in real time or close to it are considered, and their algorithms are briefly described. The significance of their use for problems of hydrodynamics and biological kinetics is shown. The necessity and possibility of applying the neural network approach and the theory of deep learning in solving the problem is proved. The main types of neural networks used in the analysis of SES data are presented. The algorithm developed to improve the accuracy of predictive modeling of hydrodynamics and biological kinetics of reservoirs of variable bathymetry can be implemented on a hybrid highperformance system.

\section{References} 147-150.

1. Lotka A.J. Contribution to the energetics of evolution // Proc. Natl. Acad. Sci. 1922. No. 8. P.

2. Volterra V. Variations and fluctuations of the number of individuals in animal species living together // Rapp. P. - V. Reun. Cons. Int. Explor. Mer. 1928. Vol. 3. P. 3-51.

3. Logofet D.O., Lesnaya E.V. The mathematics of Markov models: what Markov chains can really predict in forest successions // Ecological Modelling. 2000. Vol. 126. P. 285-298.

4. Monod J. Recherches sur la croissance des cultures bacteriennes. Paris: Hermann. 1942. 210 p.

5. Mitscherlich E.A. Das Gesert des Minimums und das Gesetz des abnehmenden Bodenertrags // Landw. Jahrb. 1909. 595 p.

6. Odum H.T. System Ecology. New York: Wiley, 1983. 644 p.

7. Gause G.F. Experimental studies on the struggle for existence: 1. Mixed population of two species of yeast // Journal of Experimental Biology. 1932. V. 9. P. 389-402.

8. Vinberg G.G. Some results of practical application of production-hydrobiological methods // Production of populations and communities of aquatic organisms and methods of its study. Sverdlovsk: Ural center of the USSR Academy of Sciences, 1985, P. 13-18. 
9. Abakumov A.I. Signs of stability of water ecosystems in mathematical models // Proceedings Of the Institute of system analysis of the Russian Academy of Sciences. System analysis of the problem of sustainable development, Moscow: ISA RAS, 2010, Vol. 54, P. 49-60.

10.Menshutkin V.V., Rukhovets L.A., Filatov N.N. Modeling of freshwater lake ecosystems (review). 2. Models of freshwater lake ecosystems. resources. 2013. Vol. 41. No. 1. P. 24-38.

11.Astrakhantsev G.P., Egorova N.B., Rukhovets L.A. Mathematical modeling of impurity distribution in reservoirs // Meteorology and hydrology. 1988. no. 6. Pp. 71-79.

12.Vorovich I.I., Gorelov A.S., Gorstko A.B., Dombrovsky Yu.A., Zhdanov Yu.A., Surkov F.A., Epstein L.V. Rational use of water resources of the Azov sea basin: mathematical models / Ed. by I.I. Vorovich. Moscow: Nauka, 1981. 360 p. 1988. $304 \mathrm{p}$

13. Marchuk G.I., Sarkisyan A.S. Mathematical modeling of ocean circulation. Moscow: Nauka,

14.Jorgensen S.E., Mejer H., Firiis M. Examination of a lake model // Ecological Modelling. 1978. Vol. 4. P. 253-278.

15.Steele J.H. The structure of marine ecosystems. - Cambrige (Massachusets): Harv. Univ. Press, 1974. - $110 \mathrm{p}$.

16.Dubois D.M. A model of patchines for prey-predator plankton populations // Ecol. Modeling. 1975. № 1. P. 67-80.

17.Sukhinov A.I., Nikitina A.V., Chistyakov A.E. Using multichannel satellite images for predictive modelling the "bloom" phytoplankton processes in shallow waters on supercomputer // Computational Mathematics and Information Technologies. 2017. V. 1. No. 2. P. 1-13.

18.Nikitina A.V., Semenyakina A.A. Mathematical modeling of eutrophication processes in Azov Sea on supercomputers // Computational Mathematics and Information Technologies. 2017. V. 1. No 1. P. 82101.

19.Sukhinov A.I., Sidoryakina V.V., Nikitina A.V., Chistyakov A.E., Filina A.A., Litvinov V.N. Mathematical modeling of nonlinear effects in dynamic of interacting plankton and fish populations of Azov Sea // Computational Mathematics and Information Technologies. 2019. V. 2. No 2. P. 83-103.

20.Nikitina A.V., Kozlov V.M., Filina A.A. Mathematical modeling of the delay process in regulation of population dynamics based on the theory of cellular automation // Computational Mathematics and Information Technologies. 2019. V. 1. No 1. P. 35-49.

21.Nikitina A.V., Kamyshnikova T.V. Mathematical modeling of pollution propagation processes and phytoplankton evolution in relation to the Taganrog Bay area. 2001. - $48 \mathrm{p}$.

22.Suykens F., Willems Y. Adaptive filtering for progressive Monte Carlo image rendering // WSCG, February, 2000.

23.Gastal E., Oliveira Adaptive manifolds for real-time high-dimensional filtering // ACM Transactions on Graphics (TOG), 31(4), 33, 2012.

24.Dammertz H., Sewtz D., Hanika J., Lensch H. Edge-Avoiding À-Trous Wavelet Transform for fast Global Illumination Filterin // High Performance Graphics, 2010.

25.Hachicuka T., Wojciech J., Weistroffer R., Dale K., Humphreys G., Zwicker M., Jensen H. Multidimensional Adaptive Sampling and Reconstruction for Ray Tracing // ACM Transactions on Graphics, Vol. 27, No. 3, Article 33, August, 2008.

26. Bauszat P., Eisemann M., Magnor M. Guided Image Filtering for Interactive High-quality Global Illumination // Computer Graphics Forum, Vol. 30, No. 4. - P. 1361 - 1368.

27.Doidge I., Jones. Probabilistic illumination-aware filtering for Monte Carlo rendering // The Visual Computer, 29(6 - 8). - P. 707 - 716, 2013. Blackwell Publishing Ltd, June, 2011.

28.Chen Y., Lin Z., Zhao X., Wang G., Gu Y. Deep learning-based classification of hyperspectral data, IEEE Journal of Selected Topics in Applied Earth Observations and Remote Sensing, v. 7, n. 6, pp. 2094 2107, 2014.

29.Zhen Z., Wang. G. Learning discriminative hierarchical features for. object recognition, IEEE Signal Process. Lett., vol. 21, no. 9, pp. 1159-1163, 2014. 
Authors:

Anton L. Leontyev, Postgraduate student of the Department of Intelligent and multiprocessor systems, South Federal University (Chekhov st., 2, Taganrog, Russian Federation), 8(918)510 29 20, Leontyev_Anton@mail.ru

Alla V. Nikitina, Dr.Sci., professor, Professor of the Department of Intelligent and multiprocessor systems, South Federal University (Chekhov st., 2, Taganrog, Russian Federation), 8(951)516 85 38, nikitina.vm@gmail.com

Margaret I. Chumak, Master student of the Department of Mathematics and computer science, Don State Technical University (DSTU) (Gagarin sq., 1, Rostov-on-Don, Russian Federation), 8(908)182 03 69, chumaaak1908@gmail.com 


\title{
Применение методов усвоения и фильтрации данных спутникового
} зондирования водоемов для прогнозного моделирования процессов эволюции планктонных популяций*

\author{
А. Л. Леонтьев ${ }^{1,2,3}$, А. В. Никитина ${ }^{1,2,3}$, М. И. Чумак ${ }^{3,4 * *}$ \\ ${ }^{1}$ Южный федеральный университет, г. Таганрог, Российская Федерация \\ ${ }^{2}$ Общество с ограниченной ответственностью «Научно-исследовательский центр супер-ЭВМ \\ и нейрокомпьютеров», г. Таганрог, Российская Федерация \\ ${ }^{3}$ Научно-технологический университет «Сириус», г. Сочи, Российская Федерация \\ ${ }^{4}$ Донской государственный технический университет, г. Ростов-на-Дону, Российская \\ Федерация
}

Работа посвящена анализу и реализации высокотехнологичных методов усвоения и фильтрации данных спутниковых наблюдений, применяемых при разработке и верификации математических моделей гидродинамики и биологической кинетики мелководных водоемов. В работе рассматривается возможность применения нейронных сетей и описываются различные методы фильтрации изображений, полученных на основе данных спутникового зондирования Земли. Рассматривается математическая модель эволюции планктонных популяций в Азовском море. Её калибровка и верификация проводится с использованием методов усвоения спутниковых наблюдений. Целью работы является создание программного инструментария, применяемого на предварительном и финальном этапах математического моделирования гидробиологических процессов мелководного водоема.

Keywords: математическое моделирование, эволюция фито-планктона, мелководный водоем, данные спутникового зондирования, нейронные сети, методы фильтрации.

\section{Авторы:}

Леонтьев Антон Леонидович, Аспирант кафедры Интеллектуальных и многопроцессорных систем, Южный федеральный университет (РФ, г. Таганрог, ул. Чехова, 2), 8(918)510 2920 , Leontyev Anton@mail.ru

Никитина Алла Валерьевна, Доктор технических наук, профессор, профессор кафедры Интеллектуальных и многопроцессорных систем, Южный федеральный университет (РФ, г. Таганрог, ул. Чехова, 2), 8(951)516 85 38, nikitina.vm@gmail.com

Чумак Маргарита Игоревна, Магистрант кафедры математики и информатики, Донской государственный технический университет (ДГТУ) (РФ, г. Ростов-на-Дону, пл. Гагарина, 1), 8(908)182 03 69, chumaaak1908@gmail.com

\footnotetext{
* Исследование выполнено при финансовой поддержке РФФИ в рамках научного проекта № 19-31-51017.

** E-mail: Leontyev_Anton@mail.ru, Nikitina.vm@gmail.com, Chumaaak1908@gmail.com.
} 